\title{
ANALYSIS OF ENTREPRENEURSHIP ORIENTATION, ADAPTABILITY OF BUSINESS ENVIRONMENT, AND INTERNAL RESOURCES COMPANY ON COMPETITIVE ADVANTAGES TO IMPROVE COMPANY PERFORMANCE
} (Study at Micro Small and Medium Enterprises Embroidered Kudus District)

\author{
Aulia Ardhian Ayuningtyas ${ }^{1}$ \\ Miyasto ${ }^{2}$ \\ Sugiarto $\mathrm{PH}^{3}$ \\ 1,2,3 Master of Management, Faculty of Economics and Business, Diponegoro \\ University
}

\begin{abstract}
Economic development in Indonesia MSMEs has an important role because the majority of Indonesia's population lives from MSME activities both in the traditional and modern sector. MSME in Central Java is also quite good. However, MSMEs in Central Java also experienced an increase in competitiveness, especially with similar businesses. Therefore, entrepreneurs are required to be able to innovate and dare to explore the resources it has for its business can continue to grow and survive amid the competition. In this study, the authors explain the condition of competitiveness of SMEs in the Kudus Regency is the business of embroidery which from year to year always decreased. Based on the result of the theoretical study directing this study developed a model with five research variables covering entrepreneurial orientation, business environment adaptability, internal resources of company, competitive advantage, and company performance. The results of the analysis show that the entrepreneurship orientation does not positively affect the competitive advantage. The adaptability of the business environment positively affects the competitive advantage. Internal resources of the company positively influence the competitive advantage. Entrepreneurship orientation positively affects the company's performance. Internal resources of the company positively affect the company's performance. Competitive advantage positively affects the company's performance.
\end{abstract}

Keywords: orientation of entrepreneurship, adaptability of the business environment, internal resources of company, competitive advantage, company performance. 


\section{INTRODUCTION}

The development of MSMEs in Central Java is quite good. Based on the data, in 2013, the number of MSMEs in Central Java reached 90,339 units with total employment absorption amounted to 480,508 people. Deputy Governor of Central Java, Drs Heru Sudjatmiko, M.Si said, although the development of MSMEs in Central Java is fairly good, there are still many problems faced by business actors, especially capital. Many MSMEs are developing but have not been bankable or do not have sufficient security to get credit, while having good character and effort, making it difficult to get a capital loan from banking and other financial institution (Tribun Jateng, December 6, 2015).

In addition to capital problems faced by MSMEs in Central Java. The weaknesses and challenges of MSMEs in Central Java as a barrier to competitiveness, among others: limited human resources, weak business networks, unfavorable business climate, limited business infrastructure, and limited market access. This phenomenon indicates the potential and the fact of competitiveness of SMEs in Central Java. Low competitiveness influences the long-term existence of a company. Porter (2008), said that competitive advantage is the basis of the company's performance to compete and grow from the value that the company is able to create for its customers and can withstand other competitive pressures in the market.

The condition of decreasing the number of requests, the number of sales, the number of assets, and profit is a phenomenon that needs special attention so that the industry can still grow and have high competitiveness. Micro Small and Medium Enterprises (MSMEs) are an important part of the economic system. MSMEs, the state is greatly helped in job creation. The emergence of new work units that use new personnel can support household income. MSMEs need to be given more attention from the government, in order to create a focused business network and to reduce unhealthy competition among small and medium business actors.

In economic development in Indonesia, MSMEs have an important role, because the majority of Indonesia's population lives from the activities of MSMEs both in the traditional and modern sector. The role of MSMEs is managed by two ministries, the Ministry of Industry and Trade and the Ministry of Cooperatives and MSME. MSME in Central Java a concerned government because spread can open up potential employment opportunities. This small industry contributes to development in various ways, among others by creating jobs, expanding the workforce for urbanization, and providing various needs and can innovate in the economy as a whole.

In other conditions that exist in Central Java in general for MSMEs in Kudus District has a separate problem regarding product innovation. Product products produced at MSME Kudus District from year to year did not change model or form. 
Models or forms used by entrepreneurs of SMEs in Kudus District do not follow the current market share. There are many studies that explain that to be able to create and maintain competitive advantage must have well-oriented entrepreneurship. Entrepreneurial entrepreneurship is defined as entrepreneur behavior to engage in innovative, risk-taking and proactive activities (Lumpkin and Dess, 1996). Entrepreneurs who have this behavior can develop effectively, improve performance, as well as the competitiveness of the company.

In the midst of increasingly fierce competition, entrepreneurs are required to continue to innovate the product. In addition, entrepreneurs are required to aggressively exploit the opportunities that exist in the environment, have the courage to take risks and able to manage and manage all the possible risks (Covin and Slevin, 1989). Entrepreneurs are also required to be able to deal with an uncertain business environment. This uncertainty hampers the company's ability to develop long-term plans and strategic decision making. The success of the entrepreneur is influenced by its ability to adapt to the environment, and the adaptability of the business environment itself can be the basis of the strategy company (Jap, 1999). To implement a strategy that can improve the efficiency and effectiveness of the company, employers must be able to use the company's internal resources well (Rose, et al, 2010). Internal resources of well-managed companies can be contributed to competitive advantage because it can reduce production cost and can easily innovate (Inmyxai and Takahashi, 2009).

MSMEs in Kudus District each year continues to increase. According to the data, MSMEs in District Kudus are well positioned and increased from 27,327 units in 2014 to 27,818 units in 2015 , an increase of $1.8 \%$. The increase is happening to SMEs in the production and trade sectors, especially the convection and apparel industry. The increasing number of MSMEs is increasing the amount of competition among businessmen in Kudus regency. However, the competition is still healthy and tends to compete for apple to apple, which occurs only in entrepreneurs who are at the same level and tend to occur in entrepreneurs who belong to medium and large. These entrepreneurs continue to innovate in its products to stay afloat amid increasingly fierce competition. Meanwhile, entrepreneurs who are small and have just pioneered their business, have not been able to compete with entrepreneurs who have long been in production although it is possible to someday become a competitor and is a threat to the big businessmen. In addition to continuing to be required to continue to innovate, small entrepreneurs face problems such as limited capital, raw materials prices continue to increase, product marketing is still limited, and technology and human resources are still very limited.

Embroidery industry in Kudus District despite long-standing attention and support from the local government, but the results have not been encouraging or 
have not reached the target as expected by the Government of Kudus Regency. Many factors that cause why empowerment did by the Government of Kudus District to empower the embroidery industry has not succeeded. In general, the factors that led to the lack of success of this government program are seen in terms of increasing the number of employers, labor, the addition of working capital/investment value, and the value of products classified as slow. The government of Kudus Regency has provided venture capital assistance, guidance to the workforce, guidance to entrepreneurs in the expansion of marketing and other facilitations.

Other obstacles faced by embroidery industry entrepreneurs in Kudus Regency are as follows: In terms of raw material prices and fluctuating raw materials, the cash payment system demanded by suppliers, the supply of raw materials that often arrive late because of the far supplier; in terms of labor, less productive workforce, less skilled labor available, many laborers choose to switch to factory labor due to higher wages, limited labor force; in terms of marketing, competition with the embroidery industry found in other areas, both within Kudus itself and outside Central Java, the entrepreneur depends heavily on orders because production is still made by order, fluctuating demand, price competition with fellow embroidery entrepreneurs, management because it is still traditionally managed, does not have a special design motif so often imitation, design that does not follow the development, the capital is still limited, especially the embroidery machines that cost quite expensive, many entrepreneurs who have not gained access to banking because of lending procedures collided on collateral, slow capital turnover.

\section{LITERATURE REVIEW}

\section{Effect of Entrepreneurship Orientation and Design Excellence}

Entrepreneurship is a pioneer to achieve sustainable and highly competitive economic growth. Entrepreneurship is one of the four pillars in building employment. Entrepreneurship-oriented companies can achieve better market targets and positions compared to their competitors (Kumalaningrum, 2012). The focus in this study on the variables entrepreneurship oriented, namely innovative, risk-taking and proactive. Innovative is the company's corporate tendency to engage and support creative ideas, inventions, experiments and processes that can produce new products, services or technologies. Dare to take risks is an opportunity-oriented thing in uncertainty in decision making. Proactive is where a company leader is able to identify opportunities, anticipate problems, see future needs and changes. H1: The entrepreneurship orientation positively affects the competitive advantage. 


\section{Effect of Business Environment Adaptability to Competitive Advantage}

According to Fogel (2001), to increase competitiveness, entrepreneurs must innovate, invest in technology, and use market-based management and market practices. According to Ahmad (2010), the business environment is very influential in economic development. Stable political and economic conditions will improve the business climate is very significant, indicated by the growing number of small businesses that are emerging and more and more product innovation to be offered. It can be concluded that the better the company can adapt to its business environment, then its competitive advantage can be increased.

H2: The adaptability of the business environment positively affects the competitive advantage.

\section{The Effect of Internal Resources on Competitive Advantage}

The company's internal resources, such as assets, capabilities, organizational processes, information, knowledge, etc. that are managed and controlled by the company allow companies to implement strategies that can improve their efficiency and effectiveness (Rose et al., 2010). Internal resources with the latest technology significantly influence the growth of the company and contribute to competitive advantage as it reduces production costs and can be easily innovated (Inmyxai and Takahashi, 2009). Resources such as brands, technology, skilled employees, contacts trade, machinery, efficient procedures, and capital, are the basis for achieving and competitive advantage.

H3: The company's internal resources positively influence the competitive advantage.

\section{Effect of Entrepreneurship Orientation on Company Performance}

The entrepreneurial orientation according to Lumpkin \& Dess (1996) has three dimensions, namely innovation, risk-taking, and proactiveness. The first dimension of entrepreneurship orientation is innovation. Innovation also explores new ideas and takes part in experiments for the development of new products to gain a competitive advantage. This is in accordance with Frishammar and Horte's (2007) research results. The second dimension is risk-taking, seen from the extent to which managers are able to commit and be bold in decisions that are at risk. a relatively safe risk to very high risk. Risk cannot be avoided despite being able to degrade performance. The third dimension is a proactive nature of forward-looking, as the prime mover in the quest for excellence to shape the environment by introducing products or facing competition in the future (Prince, 2012 in Witjaksono, 2014). H4: entrepreneurship orientation positively affects the company's performance. 


\section{Effect of Internal Resources of Company on Company Performance}

Certain types of resources owned and managed by the company have the potential to produce competitive advantage, which makes the company's performance superior (Rose et al., 2010). Internal resources of the firm such as knowledge, skilled employees, machinery, and capital are the basis for achieving performance which is superior. Resource relations and competitive advantage are strongly influenced by elements such as assets owned by the company (Rose et al., 2010). Companies that want to implement strategies that can improve their efficiency and effectiveness must be able to manage their internal resources that include all assets, organizational processes, information and knowledge (Rose et al, 2010).

H5: The company's internal resources have a positive effect on the company's performance.

\section{The Influence of Competitive Advantage on Company Performance}

The generic strategy proposed by Porter (1985), many developed into the concept of competitive advantage. Competitive advantage is the basic concept of corporate performance in the competitive market. Competitive advantage evolves from the value or benefits that can be given company for the buyers. Companies that are able to create excellence derived from Porter's generic strategy, will gain a competitive advantage. Companies that have a competitive advantage will be more successful when compared to companies that do not have a competitive strategy (Cater and Pucko, 2005).

H6: Competitive advantage positively affects the company's performance.

\section{RESEARCH METHOD}

\section{Population}

The population is a collection of individuals or research objects that have criteria and characteristics that are almost the same. The population is defined as a group of objects that have certain characteristics or characteristics (Indrianto and Supomo, 1999). The population is a combination of elements that have certain characteristics that become the center of attention of researchers because it is seen as an interesting object. Population in this research is an industrial embroidery company which is in Kudus District which amounts to 122 companies.

\section{Sample}

This research uses census technique in sampling. Census understanding according to Sugiyono (2009), is if all member of the population become sample. This technique is commonly referred to as sample saturation technique. The census is 
done when the population is relatively small or the research done wants to make a very mistake small. So based on this understanding, then the number of samples in this study are all entrepreneurs embroidery in Kudus District.

\section{Definition of Research Variables}

\section{Orientation of Entrepreneurship}

Lumpkin and Dess (1996) give a distinction between entrepreneurial orientation and entrepreneurship. Entrepreneurship is defined as a new entry. Entrepreneurship can be done by entering a fixed market or a new market. Products that can be developed can be with existing products or services or launch a new company. While the orientation of an entrepreneur is a description of new entry which is executed by the company. The entrepreneurial orientation is illustrated by processes, practices, and decision-making activities that encourage new entry. Entrepreneurship is a product of entrepreneurial orientation. Entrepreneurial entrepreneurship is a corporate behavior to engage in innovative, risk-taking and proactive activities to defeat competitors. Companies that have this behavior can develop effectively, improve performance and competitiveness.

The dimensions of entrepreneurship orientation have several dimensions, namely innovation, proactivity, aggressive tendencies to take advantage of environmental opportunities, and a willingness to take risks and manage or manage risks (Covin and Slevin, 1989 and improvements by Sexton, 1997).

Based on the above concept, this study focuses on entrepreneurial orientation on small business sector trade. So the dimensions of entrepreneurship orientation in this study developed based on the opinions developed by Covin and Slevin (1989), Lumpkin and Dess (1996), which include: (a) Innovation; entrepreneur-oriented companies are always innovating and always striving to create a renewal of what has been done; (b) Dare to take risks; is the courage to take risks in creating businesses that are different from other existing businesses (Naman and Slevin, 1993); (c) Proactive; the company will enter new markets with a step ahead of its competitors (Lumpkin and Dess, 1996).

The company's ability to coordinate marketing, inter-organizational activities, rapid response to changes in the competitive environment and anticipate every strategic change greatly affects the success of entrepreneur-oriented enterprises.

\section{Business Environment Adaptability}

The business environment is a combination factor that plays a role in entrepreneurial development and entrepreneurship and business activity. The business environment can affect the sustainability or success of a company. Many researchers have shown different effects between the business environment and 
entrepreneurship (Fogel, 1994; Brandstatter, 1997; Zapalska and Zapalska, 1999; Singh, 2000; Ahmad et al., 2010). Wennekers et al (2002), argues that technology, economic, cultural and governmental developments influence the creation of opportunities for a business. Meanwhile, according to Fogel (1994), the government can influence the market mechanism, make its function more efficient by changing the conditions that make imperfect markets or rigid regulations. Changes in the business environment have a negative and positive effect on the growth or failure of small businesses (Ahmad et al., 2010).

Demographic, economic, political, legal, socio-cultural and technological segments are segments encompassed by the adaptability of the business environment in the wider society. It is necessary to analyze the business environment adaptability that encompasses the threats of new competitors, supplier strength, buyer power, the existence of replacement goods and the intensity of competition (Porter, 1980). The success of MSMEs after the start of its business activities is influenced by the adaptability of its business environment and the adaptability of the business environment itself can serve as the basis of the company's strategy (Jap, 1999).

Companies must be in tune with the external environment to be successful for long periods of time. Environmental desires must have strategic conformity to what the company offers. The needs of the company also must be in accordance with what can be provided by the environment. According to predictions, there is no certainty for the company will be better for the next few years. The uncertainty is the unity between the level of complexity and the rate of change in the external environment of the organization. This uncertainty impedes the ability of firms to develop long-term plans and to make strategic decisions, to keep companies in balance with the external environment. The uncertainty poses a threat to corporate management (Hunger, J.David \& Thomas L. Wheleen, 2003 in Zulaikha, 2003).

\section{Company Internal Resources}

Resource-Based View of firm states that certain types of resources owned and managed by a company have the potential to produce a competitive advantage that will provide superior corporate performance (Rose et al., 2010). Conclusions from Wernerfelt (1984) in Rose et al (2010) are resources such as brands, technology, skilled employees, trade contacts, machinery, efficient procedures, and capital are the basis for achieving and continuing competitive advantage. The relationship between resources and competitive advantage is strongly influenced by elements such as assets owned by the company (Rose et al, 2010).

Large companies that can control their internal resources can obtain low-cost business finance and build strong networks with their external stakeholders, such 
as consumers, suppliers, banks, and governments (Inmyxai and Takahashi, 2009). The company's internal controlled resources enable companies to implement strategies that can improve their efficiency and effectiveness (Rose et al., 2010). Internal resources with high technology owned companies can improve profitability and provide better quality both on products and services produced. Internal resources with the latest technology very significant effect on the growth of the company and contribute to competitive advantage because it can reduce production costs and can easily to innovate (Inmyxai and Takahashi, 2009).

\section{Competitive Advantages}

The competitive advantage described (Bharadwaj et al, 1993), is the result of implementing a strategy that uses a variety of resources owned by the company. Employee expertise is a company asset to make the employee an important part of the company. Companies that are able to develop their employees well will make the company superior. Human resource-based business strategies will be difficult to imitate by competitors.

Porter (1990) explains that competitive advantage (competitive advantage) is the heart of marketing performance to face competition. Competitive advantage is defined as a benefits strategy of companies that collaborate to create a more effective competitive advantage in the market. This strategy should be designed to realize sustainable competitive advantage so that the company can dominate both in the old market and in new markets. The competitive advantage grows from the value or benefits the company provides for its buyers. Competitive advantage can also be defined as the unique position of enterprise development in comparison with a competitor. The real evidence of competitive advantage is the superior position of the company both in the industry and in the market (Bamberger in Cater and Pucko, 2005), where superiority depends on how the customer sees it. For example, a company can create a superior product, but if the customer does not see it as a superior product, the company may not grow into a competitive advantage and make its product better than its competitors.

Indicators - indicators applied to measure the competitive advantage of a company is the uniqueness, quality, and price of competing products. The uniqueness of the product is the company's advantage in creating a product that has artistic value in accordance with customer tastes. The quality of the product is the product quality that can be received by the customer either the design and the type of product. The third indicator is the price of a competing product is the value given by the company to a product that is tailored to the value of the product in the market. 
Company performance

Sales growth, employment growth, income growth and growth in market share (shareholder growth model) are important indicators in achieving company performance (Kim and Choi, 1994; Lee and Miller, 1996 Miles et al., 2000; Hadjimanolis, 2000). Another important indicator of company performance is the number of buyers (Razzak, 2005). The success of the company, especially UMKM is influenced by the ability of the owner or manager in managing the resources owned, as well as the ability to set priority strategies to be taken in accordance with the objectives to be achieved company. Megginson (1994), explaining that the freedom of owners or managers in the decision making decisions, taking initiative and setting strategic policies have an effect on business performance. Prahalad and Hamel (1990) state that business can excel if the management has to consolidate its technological and production capabilities into a competence, which gives the strength for every individual in the organization to always be adapting rapidly to the ever-changing marketplace. Businesses will be able to maintain long-term benefits if they have the ability to create low-cost products and faster manufacturing times compared to their competitors.

\section{Method of collecting data}

To collect research data, questionnaires were chosen as a data collection method in this research. The questionnaire is an instrument of collecting data or information which operated into item or question form. Preparation of questionnaires is done in the hope to know what variables that according to the respondent is important. Observation, namely data collection through direct observation to the object research. Data obtained through observation is data about field conditions and other data related to the object of research. Literature study, which is collecting data obtained by reading the literature and previous research related to the problems studied and related data related to this research.

\section{DATA ANALYSIS AND DISCUSSION}

\section{Analysis of SEM Assumptions}

Data Normality

Evaluation of normality is done by using criteria of critical ratio skewness value equal to $\pm 2,58$ at the level of significance 0,01 . The results of the normality data output are shown in the following table 1. 
Table 1

The Result of Data Normality Testing

\begin{tabular}{|l|rrrrrr|}
\hline Variable & min & $\max$ & Skew & c.r. & kurtosis & c.r. \\
\hline x17 & 4,000 & 7,000 &,- 338 & $-1,526$ &,- 861 & $-1,942$ \\
x18 & 4,000 & 7,000 &,- 440 & $-1,985$ &,- 516 & $-1,163$ \\
x19 & 4,000 & 7,000 &,- 429 & $-1,936$ &,- 346 &,- 779 \\
x20 & 4,000 & 7,000 &,- 309 & $-1,395$ &,- 585 & $-1,318$ \\
x16 & 4,000 & 7,000 &,- 374 & $-1,687$ &,- 363 &,- 818 \\
x15 & 4,000 & 7,000 &,- 387 & $-1,744$ &,- 487 & $-1,098$ \\
x14 & 4,000 & 7,000 &,- 284 & $-1,280$ &,- 765 & $-1,724$ \\
x13 & 4,000 & 7,000 &,- 351 & $-1,581$ &,- 227 &,- 512 \\
x12 & 4,000 & 7,000 &, 016 &, 072 &,- 819 & $-1,846$ \\
x11 & 4,000 & 7,000 &,- 253 & $-1,140$ &,- 689 & $-1,553$ \\
x10 & 4,000 & 7,000 &,- 265 & $-1,195$ &,- 420 &,- 948 \\
x7 & 4,000 & 7,000 &,- 144 &,- 650 &,- 666 & $-1,502$ \\
x8 & 4,000 & 7,000 &, 091 & -412 &,- 691 & $-1,559$ \\
x9 & 4,000 & 7,000 &,- 244 & $-1,100$ &,- 342 &,- 772 \\
x6 & 4,000 & 7,000 &,- 199 &,- 898 &,- 411 &,- 927 \\
x6 & 4,000 & 7,000 &,- 358 & $-1,614$ &,- 513 & $-1,156$ \\
x4 & 4,000 & 7,000 &,- 133 &,- 601 &,- 721 & $-1,625$ \\
x3 & 4,000 & 7,000 &,- 278 & $-1,253$ &,- 789 & $-1,778$ \\
x2 & 4,000 & 7,000 &,- 167 & -753 &,- 351 &,- 792 \\
x1 & 4,000 & 7,000 &,- 242 & $-1,089$ &,- 264 &,- 595 \\
Multivariate & & & & & 4,883 &, 909 \\
\hline
\end{tabular}

From the critical ratio value of skewness value, all indicators indicate that the data is normally distributed because the value is below 2.58 .

\section{Outlier valuation}

Detection of multivariate outliers is done by considering the value of the distance Mahalanobis. The criterion used is based on the value of Chi-Squares on degrees of freedom (degree of freedom) 20 that is the number of variable indicators at significance level $p=0.001$. Mahalanobis distance $(20: 0.001)=45,315$. This means that all cases that have a Mahalanobis distance greater than 45.315 are multivariate outliers. The output shows none of the cases that have a distance Mahalanobis value under 45.315 . So it can be concluded that the data on the study did not find any multivariate outlier.

\section{Evaluation of Multicollinearity}

Multicollinearity can be seen through the determinants of the covariance matrix. Very small determinant values indicate the presence of multicollinearity or singularity problems so that the data can not be used for research (Tabchnick and Fidell, 1998). The result of the data using AMOS yields the Determinant of sample covariance matrix $=2,001$. This value is above zero which means there is no problem multicollinearity and singularity in the data. 


\section{Reliability Test}

Reliability is a measure of internal consistency of indicators of a form variable that indicates the degree to which each indicator identifies a common characteristic variable. This can be calculated by composite construct reliability and extracted variance. The cut of the value of construct reliability is at least 0.7 and the cut of value for extracted variance is at least 0.05 . Nunally and Bernstein stated that in a moderate exploratory study the reliability of $0,5-0,6$ is sufficient to justify a research result. The variables tested for reliability are 5 variables: entrepreneurship orientation, business environment adaptability, internal resources of company, competitive advantage, company performance.

\section{Table 2}

\section{Reliability Test Results}

\begin{tabular}{|c|c|c|c|c|}
\hline Konstruk & $\begin{array}{l}\text { Reliabilitas } \\
\text { (Cronbach } \alpha)\end{array}$ & $\begin{array}{c}\text { Item } \\
\text { (indikator) }\end{array}$ & $\begin{array}{c}\text { Corrected } \\
\text { item-Total } \\
\text { Correlation }\end{array}$ & $\begin{array}{l}\text { Cronbach's } \\
\text { a if item } \\
\text { Deleted }\end{array}$ \\
\hline \multirow{3}{*}{$\begin{array}{c}\text { Orientasi } \\
\text { Kewirausahaan }\end{array}$} & \multirow{3}{*}{0,872} & $\mathrm{x} 1$ & 0,739 & 0,834 \\
\hline & & $\mathrm{x} 2$ & 0,799 & 0,779 \\
\hline & & $\mathrm{x} 3$ & 0,727 & 0,844 \\
\hline \multirow{3}{*}{ Adaptabilitas } & \multirow{3}{*}{0,819} & $x 4$ & 0,696 & 0,727 \\
\hline & & $\mathrm{x} 5$ & 0,655 & 0,769 \\
\hline & & $\mathrm{x} 6$ & 0,666 & 0,758 \\
\hline \multirow{6}{*}{ Sumber Daya Internal } & \multirow{6}{*}{0,921} & $\mathrm{x} 7$ & 0,765 & 0,908 \\
\hline & & $x 8$ & 0,720 & 0,914 \\
\hline & & $\mathrm{x} 9$ & 0,816 & 0,901 \\
\hline & & $\mathrm{x} 10$ & 0,759 & 0,908 \\
\hline & & $\mathrm{x} 11$ & 0,825 & 0,899 \\
\hline & & $\mathrm{x} 12$ & 0,757 & 0,909 \\
\hline \multirow{4}{*}{ Keunggulan Bersaing } & \multirow{4}{*}{0,913} & $\mathrm{x} 13$ & 0,764 & 0,900 \\
\hline & & $\mathrm{x} 14$ & 0,802 & 0,887 \\
\hline & & $\mathrm{x} 15$ & 0,807 & 0,885 \\
\hline & & $\mathrm{x} 16$ & 0,836 & 0,874 \\
\hline \multirow{4}{*}{ Kinerja } & \multirow{4}{*}{0,880} & $\mathrm{x} 17$ & 0,748 & 0,844 \\
\hline & & $\mathrm{x} 18$ & 0,717 & 0,856 \\
\hline & & $\mathrm{x} 19$ & 0,722 & 0,854 \\
\hline & & $\mathrm{x} 20$ & 0,778 & 0,832 \\
\hline
\end{tabular}

Reliability test results in table 2 state that the five variables of entrepreneurship orientation, business environment adaptability, internal resources company, competitive advantage, and company performance is reliable. This is evidenced by the value of construct reliability above 0.872 of entrepreneurship orientation, business environment adaptability with value 0.819 , internal resources with value 0.912 , competitive advantage with value, 0.913 , company performance with a value of 0.880 .

\section{Hypothesis Testing Model Feasibility Testing}

The results of data processing for the analysis of a full SEM model is presented in figure 1. 
Figure 1

Structural Equation Modeling

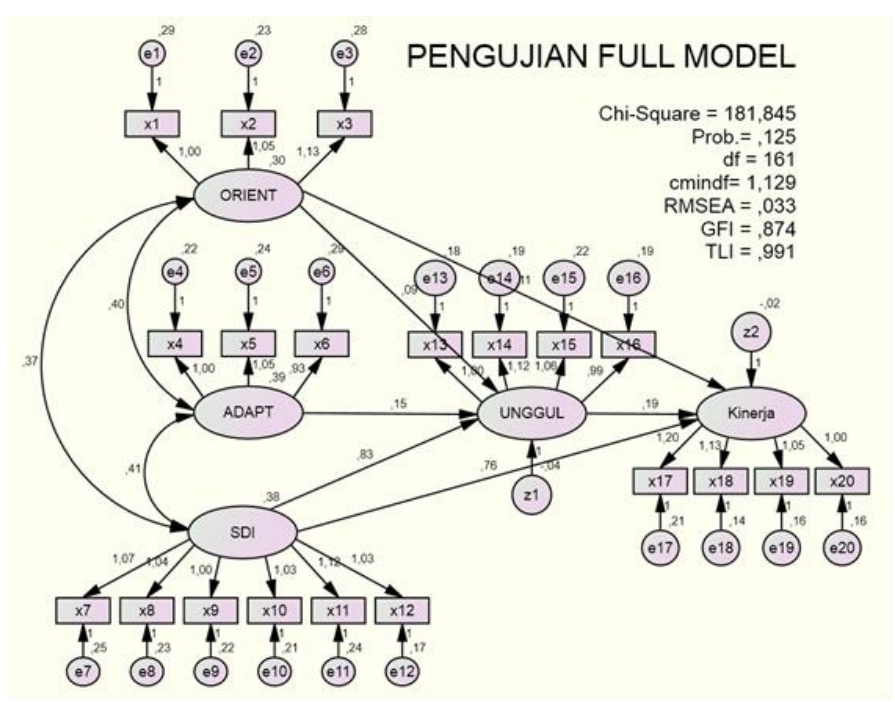

Table 3

Full Model Test Results

\begin{tabular}{|c|c|c|c|}
\hline Kriteria & Cut off Value & Hasil & Evaluasi \\
\hline Chi-Square & $\begin{array}{c}\chi^{2} \text { dengan df: } 161 ; \\
\text { p: } 5 \%=191,609\end{array}$ & 181,845 & Baik \\
\hline Probability & $\geq 0,05$ & 0,125 & Signifikan \\
\hline GFI & $\geq 0,90$ & 0,874 & Baik \\
\hline ILI & $\geq 0,95$ & 0.945 & Baik \\
\hline CFI & $\geq 0,95$ & 0,992 & Baik \\
\hline CMIN/DF & $\leq 2,00$ & 1,129 & Baik \\
\hline RMSEA & $\leq 0,08$ & 0,033 & Baik \\
\hline
\end{tabular}

The results in table 3 indicate that this model is appropriate according to data or fit to available data. The Model of SEM analysis results have met the criteria of the Goodness of Fit Index Criteria: chi square $=181,845$, probability $=0.125, \mathrm{GFI}=$ $0.874, \mathrm{TLI}=0.945, \mathrm{CFI}=0.992, \mathrm{CMIN} / \mathrm{DF}=1.129, \mathrm{RMSEA}=0.033$.

\section{Evaluation of Parameter Value}

Testing of the proposed hypothesis can be seen from the results of standardized regression coefficients. The results of the estimation output can be seen in the following table 4 . 
Table 4

Results Regression Weights Full Model

\begin{tabular}{|c|c|c|c|c|c|c|}
\hline & & Estimate & S.E. & C.R. & $\mathrm{P}$ & Label \\
\hline Keungqulan Bersaing & $<$ SDI & 830 &, 130 & 6,379 & *** & par_20 \\
\hline Keungqulan Bersaing & <- ORIENT & ,087 & ,058 & 1,499 & 134 & par_22 \\
\hline Keunggulan Bersaing & «- ADAPT & 146 & ,072 & 2,020 & ,043 & par_23 \\
\hline KINERJA & <-- Keungqulan Bersaing & 188 &, 080 & 2,343 & 019 & par_19 \\
\hline KINERJA & $<-$ ORIENT & 112 &, 049 & 2,302 & ,021 & par_21 \\
\hline KINERJA & $<-$ SDI $_{1}$ & ,765 & ,126 & 6,045 & *** & par_24 \\
\hline $\mathrm{x} 1$ & $\leftrightarrow-$ ORIENT & 1,000 & & & & \\
\hline $\mathrm{x} 2$ & $\ldots$ ORIENT & 1,053 & 110 & 9,557 & *** & par_1 \\
\hline$\times 3$ & -- ORIENT & 1,125 & 120 & 9,414 & *** & par_2 \\
\hline x4 & $\leftrightarrow$ ADAPT & 1,000 & & & & \\
\hline $\mathrm{x} 5$ & $\longleftrightarrow$ ADAPT & 1,048 & ,094 & 11,144 & *** & par_3 3 \\
\hline x6 & $\leftrightarrow$ ADAPT & 931 & ,094 & 9,873 & *** & par_4 \\
\hline x9 & «- SDI & 1,000 & & & & \\
\hline $\mathrm{x} 8$ & <-sDI & 1,036 & 099 & 10,456 & *** & par_5 \\
\hline x7 & <-. SDI & 1,066 & 103 & 10,321 & *** & par_6 \\
\hline x10 & «SDI & 1,034 & ,098 & 10,562 & $* * *$ & par_7 \\
\hline $\mathrm{x} 11$ & « SDI & 1,116 & 105 & 10,654 & *** & par_8 \\
\hline $\mathrm{x} 12$ & <-. SDI & 1,030 & ,093 & 11,063 & $* *$ & par_9 \\
\hline $\mathrm{x} 13$ & «- Keungqulan Bersaing & 1,000 & & & & \\
\hline x14 & <-- Keungqulan Bersaing & 1,120 &, 089 & 12,553 & *** & par_13 \\
\hline x15 & <-- Keunggulan Bersaing & 1,064 & 090 & 11,814 & *** & par_14 \\
\hline x16 & <-- Keungqulan Bersaing & 987 & ,084 & 11,702 & *** & par_15 \\
\hline x20 & <- KINERJA & 1,000 & & & & \\
\hline x19 & «- KINERJA & 1,051 & 080 & 13,122 & *** & par_16 \\
\hline x18 & <-. KINERJA & 1,125 & 080 & 14,089 & $* * *$ & par_17 \\
\hline $\mathrm{x} 17$ & K- KINERJA & 1,204 &, 092 & 13,153 & $* * *$ & par_18 \\
\hline
\end{tabular}

From the output of the parameter, coefficient is clear that not all hypothesis proposed in this research accepted. Acceptance of the hypothesis is done by looking at the value of Critical Ratio (CR) above 1.96 with Probability $(P)$ below 0.05 . The test results show that significant influence is only in the relationship of business environment Adaptability with competitive advantage $(\mathrm{H} 2)$, internal resources of company to competitive advantage ( $\mathrm{H} 3)$, entrepreneurship orientation to company performance $(\mathrm{H} 4)$, Internal resources of company to company performance (H5), Competitive advantage to company performance $(\mathrm{H} 6)$.

\section{Hypothesis Testing 1}

H1: The entrepreneurship orientation positively affects the competitive advantage. In this study, entrepreneurial orientation has a negative effect on competitive advantage. Based on the results of data processing known that the value of Critical Ratio (CR) the influence between entrepreneurship orientation variables to competitive advantage is 1.499 and Probability $(\mathrm{P})$ value of 0.134 , thus it can be said that the first hypothesis of this study was rejected. 


\section{Hypothesis Testing 2}

H2: The adaptability of the business environment positively affects the competitive advantage.

In this research, the adaptability of the business environment has a positive effect on the competitive advantage. Based on the result of data processing, it is known that the value of Critical Ratio (CR) influence between business environment adaptability variable to competitive advantage is 2.020 and Probability $(P)$ value is 0,043 , thus it can be said that the second hypothesis of this research is accepted.

\section{Hypothesis Testing 3}

H3: Internal resources positively affect the competitive advantage.

In this study, internal resources have a positive effect on competitive advantage. Based on the result of data processing, it is known that the value of Critical Ratio (CR) influence between internal resource variables to competitive advantage is 6.379 and Probability $(P)$ value is 0.000 , thus it can be said that the third hypothesis of this research is accepted.

\section{Hypothesis Testing 4}

H4: entrepreneurship orientation positively affects the company's performance.

In this research, entrepreneurship orientation has a positive effect on company performance. Based on the result of data processing known that Critical Ratio (CR) value of influence between entrepreneurship orientation variable to company performance is equal to 2,302 and Probability value $(P)$ equal to 0,021 , hence can be said that fourth hypothesis this research accepted.

\section{Hypothesis Testing 5}

H5: Internal resources positively affect the company's performance.

In this study, internal resources have a positive effect on company performance. Based on the result of data processing, it is known that the value of Critical Ratio $(\mathrm{CR})$ influence between internal resource variables on company performance is 6,045 and Probability $(P)$ value is 0.000 , thus it can be said that the fifth hypothesis of this research is accepted.

\section{Hypothesis Testing 6}

H6: Competitive advantage positively affects the company's performance.

In this study, competitive advantage has a positive effect on company performance. Based on the result from data processing, it is known that the Critical Ratio (CR) value between competitiveness variable to company performance is 2,343 and 
Probability $(P)$ is 0,019 , so it can be said that the sixth hypothesis of this research is accepted.

\section{CONCLUSIONS AND SUGGESTIONS Conclusions}

Companies cannot afford to innovate their products so that there is no significant competition among business actors, because of the similarity of information, technology, resources, and even capital. The results show that entrepreneurship orientation has no effect $(C R: 1,499)$ and is not significant to a competitive advantage. Companies or business actors are able to recognize the condition of the environment by being able to describe the desires of customers, recognize business competition carefully, to maintain good relationships with its suppliers. This condition can positively affect the improvement of competitive advantage. The results showed a positive influence (CR: 2.020) and significant to a competitive advantage. Companies that are able to manage the company's internal resources well, can increase the added value for the resulting product so that the company will have a better competitive advantage than its competitors. The results showed that the company's internal resources have a positive effect (CR: 6,379) and significant to a competitive advantage.

The ability of companies to innovate, be proactive and have the courage in risk taking can produce innovative products and able to reach a wider market. This condition can improve company performance. The results showed that entrepreneurship orientation has a positive effect (CR: 2,302) and significant to company performance. Companies that are able to utilize their internal resources effectively and efficiently can improve company performance. The results showed that the company's internal resources have a positive effect (CR: 6,045) and significant to company performance. Companies that are able to deliver more value to their products will be able to improve company performance. The results showed that the company's competitive advantage had a positive effect $(\mathrm{CR}: 2,343)$ and significant to company performance.

\section{Managerial implications}

The results of this study are expected to give implications not only in theoretical development but also managerial development so that the results of this study are useful in addition to the enrichment of science, especially strategic management but also useful for business development that becomes the object of research. Some of the managerial implementations of the results of this study which is expected to contribute to the development of embroidery business in Kudus District are as follows: 


\section{a. Internal resources}

Internal resources of the company became the biggest influence in this research. This is evidenced by the value of an estimate of 0.813 to competitive advantage and 2.852 affect the business performance. Here are the indicators that affect the company's internal resources:

- Technology, entrepreneurs implement the business strategy in this case by using a computerized embroidery machine, so that the resulting product can be more variation.

- Employee skills, entrepreneurs implement the business strategy in this case by employing good employees who are able to operate computer embroidery machines or traditional embroidery machines.

- The ability of the company, the company is required to have coordinated management capabilities so that each resource can be managed properly.

- Capital, the entrepreneur implements a strategic business in this case not only the capital used for the purchase of raw materials, but for the purchase of computerized production and embroidery machines.

- Information, entrepreneurs implement by continuously updating information or fashion trend that is in the public interest that is by following the exhibition of fashion products.

- Knowledge of human resources, entrepreneurs implement by providing training to improve the knowledge of human resources either on the latest technology or embroidery techniques.

\section{b. Company performance}

Company performance becomes the variables influenced by all variables. The most influential variables are internal resources of 0.882 , competitive advantage of 0.184 , the entrepreneurial orientation of 0.109 , and business environment adaptability of 0.027 . Here are the indicators that affect the company's performance:

- Sales growth, entrepreneurs implement business strategies in this regard with new products generated by employers attract purchasing power for past customers.

- The growth of the customer, the entrepreneur implements the business strategy in this case with the product generated by the entrepreneur withdraws the purchasing power for new customers because of their characteristics and quality.

- Profit growth, entrepreneurs implement the business strategy in this regard while maintaining quality despite price rises.

- Market growth, the entrepreneur implements the business strategy in this regard by making the product to be offered to new markets with examples already in place and being sold. 


\section{c. Competitive advantage}

Design excellence becomes a variable that is influenced by all other variables. The most influential variables are internal resources of 0.813 , business environment adaptability of 0.145 , the entrepreneurial orientation of 0.76 . Here are the indicators that affect competitive advantage:

- Uniqueness, the entrepreneur implements the business strategy in this case by making embroidery with embroidery products that have never been found elsewhere, such as embroidered shoe products.

- Not easily replaceable, entrepreneurs implement the business strategy in this case with the quality of products produced by entrepreneurs embroidery is quite good and durable (not quickly broken).

- Competitive prices, employers implement the business strategy in this case by selling their embroidery products at acceptable prices in the community and competing fairly with other entrepreneurs.

- Not easily imitated, the entrepreneur implements the business strategy in this case by making embroidery products that still use traditional embroidery machines.

\section{d. Entrepreneurship Orientation}

- Entrepreneurship orientation becomes the influence of this research. This is evidenced by the value of the estimate of 0.076 affect the competitive advantage and 0.109 affect the performance of the company. Here are the indicators that affect innovation:

Proactive, entrepreneurs implement business strategies by continuing to follow the development of fashion embroidery either by searching for information on the internet or following fashion product exhibitions.

- Innovation, entrepreneurs implement the business strategy by continuously innovating both from the innovation of embroidery products, motives that have never existed or technology that certainly does not eliminate the character of embroidery Kudus district itself.

- Courage to take risks, entrepreneurs implement business strategies boldly speculate on annual product trends or prices.

\section{e. Adaptability of the business environment}

Entrepreneurship orientation becomes the influence of this research. This is evidenced by the value of the estimate of 0.076 affect the competitive advantage and 0.109 affect the performance of the company. Here are the indicators that affect innovation: 
- The ability to understand the customer, the entrepreneur implements the business strategy by understanding the desire of the customer when receiving the order. Entrepreneurs should be able to describe the customer's wishes in the form of products, the timely production period, as well as providing competitive prices so that customers will repeat orders.

- Ability to work with suppliers, entrepreneurs to implement business strategies by ensuring the selected suppliers can meet the needs of quality raw materials, affordable prices and timely delivery of raw materials, so as not to hinder the production process.

The ability to understand competitors, entrepreneurs implement business strategies by understanding competitors, because, by understanding competitors, entrepreneurs are able to describe where the direction of fashion trends will go, so entrepreneurs continue to have a place in the market.

\section{Suggestions}

The variables of entrepreneurship orientation, business environment adaptability, internal resources of the company, and competitive advantage, can only explain the dynamics of the company's performance of 0.70 or $70 \%$, while $30 \%$ is influenced by other variables that have not been explained. The indirect influence of entrepreneurship orientation variable, business environment adaptability and internal resources of the company to company performance through competitive advantage small value, that is each $0,14,0,27$, and 0,149 . This value indicates that the competitive advantage of its influence is relatively weak in mediating market orientation and innovation on company performance.

From the limitations that exist in this research can be an idea to develop research in the future. The proposed research extension is to select other indicators that theoretically have the ability to measure other supporting variables in order to better demonstrate their influence in improving company performance, especially in the SME sector. Suggested variables include innovation and market orientation.

\section{REFERENCES}

Ahmad, Syed Zamberi and Siri Roland Xavier. (2012). "Entrepreneurial Environments and Growth: Evidence from Malaysia GEM data". Journal of Chinese Entrepreneurship Vol. 4 No.1

Aliyu, Mukhtar Shehu; Rogo, Halilu Bello; Mahmood, Rosli. (2015). "Knowledge Management, Entrepreneurial Orientation, and Firm Performance: The Role of Organizational Culture". Asian Social Science.140-152. 
Bharadwaj, S.G.P.R. Varadarajan, et al. (1993). "Sustainable Competitive Advantage in Service Industries: A Conceptual Model and Research Propositions. "Journal of Marketing57 (October): pp. 83 - 100.

Cater, Tomaz. Pucko, Danijel. "How Competitive Advantage Influences Firm Performance: The Case of Slovenian Firms". Economic and Business Review 7 (2).119-135.

Fogel, Georgine. (2001). "An Analysis of Entrepreneurial Environment and Enterprise Development in Hungary". Journal of Small Business Management 39 (1), pg. 103-109

Kim, Youngbae., Y. Choi (1994) "Strategic Types and Performances of Small Firms in Korea", International Small Bussiness journal, 13, 1, pp. 13-25

Lumpkin, G.T and G.G. Dess (1996), "Clarifying the Entrepreneurial Orientation Construct and Linking It to Performance", The Academy of Management Review 21 , no.1, 135-172.

Mahfooz, A Ansari, Rehana Aafaqi, and Sharmila Jayasingam. (2000). "Entrepreneurial Success, Gender, Leadership Behaviour". Journal of International Bussiness and Entrepreneurship, Vol.8, No.2.

Miller, Danny (1983), "The Correlates of Entrepreneurship in Three Types of Firms", Management Science 29, 770-791.

Miles, P Morgan., Covin G Jeffrey., Heeley b Michael (2000), "The Relationship Between Environmental Dynamism and Small Firm structure, strategy, and Performance". Journal of Marketing Theory and Practice. Pp. 63-74.

Monsur, Shah Mohammad Tanvir; Takahashi Yoshi. (2012). "Improvement of Firm Performance by Achieving Competitive Advantage through Vertical Integration in the Apparel Industry of Bangladesh". Asian Economic and Financial Review 2 (6): 687-712.

Porter, M.E. (1985). "Competitive Advantage: Creating and Sustaining Superior Performance". New York: The Free Press, First Edition.

Porter, M. E., (1990), “Competitive Strategy”, The Free Press, New York. P. 20.

Rauch, Andreas, Johan Wiklund, Michael Frese, and G. T. Lumpkin (2006), "Entrepreneurial Orientation and Business Performance: Cumulative Empirical Evidence". Frontiers of Entrepreneurship Research, 164-177.

Razzak, A and Raihan, S. (2008)."Venturing Into a Quota Free World: The Readymade Garment Industry of Bangladesh". Pathak Shomabesh, Dhaka. 
Rose, Raduan Che, Haslinda Abdullah, and Alimin Ismail Ismad. (2010). "A Review on the Relationship Between Organizational Resources, Competitive Advantage and Performance". The Journal of International Social Research, Vol.3/11.

Singh, Rajwinder; H.S.Sandhu; B.A. Metri; and Rajinder Kaur. (2010). "Relating Organised Retail Supply Chain Management Practiced, Competitive Advantage and Organizational Performance". Vision 14.3.173-190. 